\title{
ELECTROSTATIC PRECIPITATOR TRAINING COURSE
}

H O Egenes

M.Sc(Eng), MIEE, ACIS, Pr. Eng.

\section{FORMATION AND FUNCTION OF THE A.P.C.O.T. COMMITTEE}

The Steering Committee, Air Pollution Control Technologies (A.P.C.O.T.), was formed during 1985. The need for this committee was perceived by the co-ordinators of the Foundation for Research Development's (F.R.D.) Atmosphere and Energy Programmes of the C.S.I.R. as well as the Chief Air Pollution Control Officer. Certain research work on energy-related pollution problems was in progress at the time and it was considered that a coordinating body would be in a better position to identify South Africa's future needs in air pollution control technologies and to develop strategies for meeting these needs.

The A.P.C.O.T. Committee was initially administered by the National Institute for Chemical Engineering Research, but has recently been acknowledged as a sub-committee of the National Energy Council. The main object of A.P.C.O.T. is both to co-ordinate efforts in applying the most appropriate emission control technologies and to act as a funding body for research and development. One of the first tasks was to evaluate user experience with existing equipment. Since the electrostatic precipitator is the most common gas cleaning device used by industry, this equipment was tackled as the first main project of the committee. Resulting from this investigation, it was evident that a training course in the operation and maintenance of electrostatic precipitators would be of benefit to industry. A suitable presentation was, therefore, prepared by the A.P.C.O.T. Committee.

Because the course is basically practical in nature, it was evident that a Technikon would be the most appropriate venue. An added advantage is that a Technikon certificate reflecting the results of the examination is issued at the end of the course. Two sessions have been completed, both at the Pretoria Technikon, attended by in excess of 70 students. There is still a demand for the course.

\section{THE COURSE CONCEPT}

Both the practical and theoretical aspects of the precipitator operation and maintenance are dealt with in detail. The examination, however, is biased towards practical and safety requirements. More theory is included to a degree that may be beyond the normal operator, but this is intended to satisfy the needs of the more serious student. It must be borne in mind that students from M.Sc. to operator level have attended the course at the same time.
A deeper understanding of the basic physics of electrostatic precipitation is of value as reference when addressing the more difficult problems. The examination, however, does not require a knowledge of the more theoretical concepts.

\section{CONTENT OF THE COURSE}

The Course document consists of four modules. Module 1 illustrates some of the health aspects of polluted air as a motivation for proper operation of gas cleaning plant. It also discusses some early developments in precipitator design. The first attempt to apply the principle of electrostatic attraction to particle collection was made during 1885 as a result of the experiments of Sir Arthur Lodge. This comprised an installation at a lead smelting works in Wales.

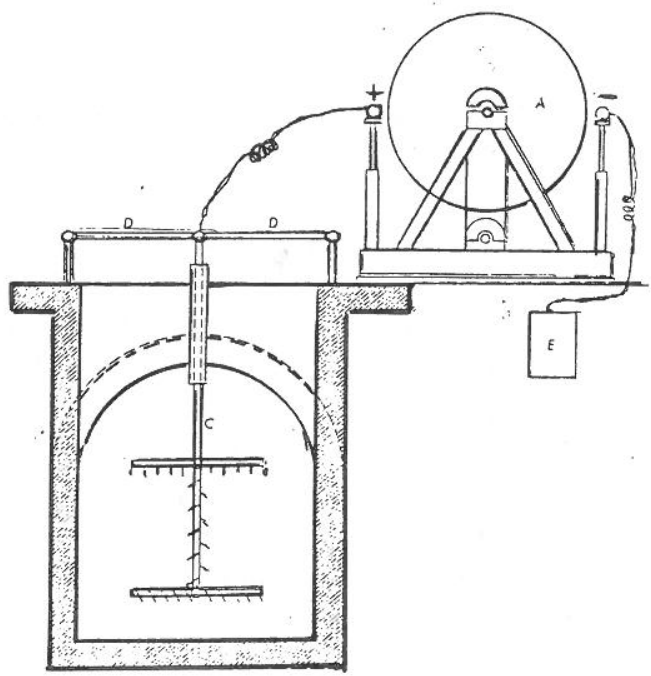

First electrostatic Precipitator

This device was energised by means of a Wimshurst Machine consisting of two glass plates, each five feet in diameter and driven by a one horsepower steam engine. The device failed, not principally because of the primitive method of energisation, but due to the unfortunate choice of trying it out on lead fume, which due to its high resistivity is one of the most difficult materials to precipitate. It is of interest to note that problems of high resistivity and particle charging are still with us, having only partially succumbed to modern technology. 
The main emphasis of the module is dedicated to familiarisation with the electrostatic precipitator. This includes a section on definitions and terminology, followed by a discussion of the design and function of the various precipitator systems. Special attention is given to the development of the high voltage equipment.

Module 2 moves on to deal with the theory of operation and with the development of the various control systems. It is here that the basic physics of electrostatic precipitation is developed. The nature of gaseous ions and the part they play in particle charging is explained.

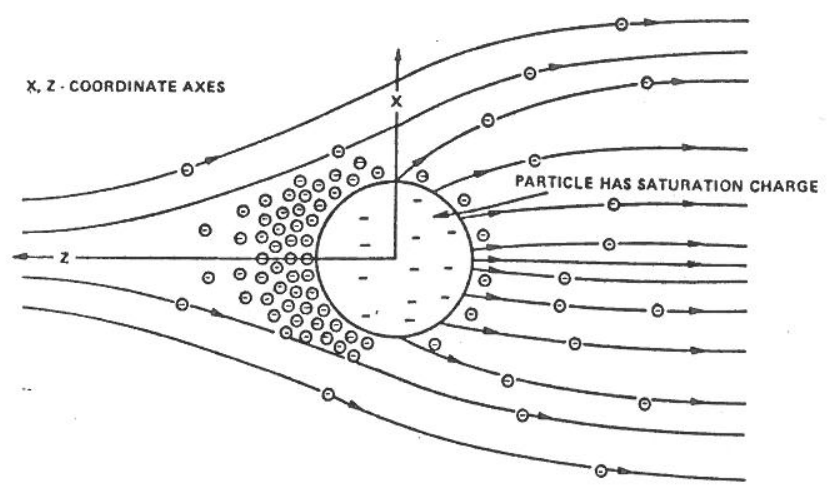

Particle charging by negative ion impact

The mechanism of particle charging is different for the larger and sub-micron size particles, the latter being more difficult to precipitate. In the following diagram the mecanisms of particle charging and migration to the collecting electrodes are depicted.
In this diagram, the action takes place from left to right. The electric field accelerates the electrons at " $A$ ", " $B$ " represents the corona glow. Positive and negative ions are formed at "C", the negative ions adhering to the dust particle at "D".

The importance of the corona discharge and the effects of dust burden and resistivity is mentioned. In particular, dust resistivity is temperature dependant, there being upper and lower limits for optimum resistivity.

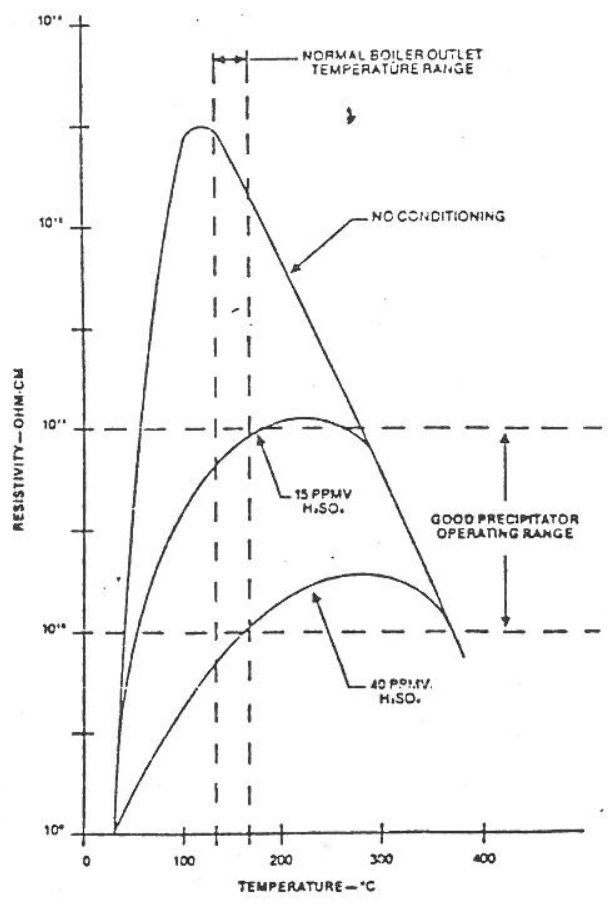

Resistivity - Temperature with and without flue gas conditioning agents

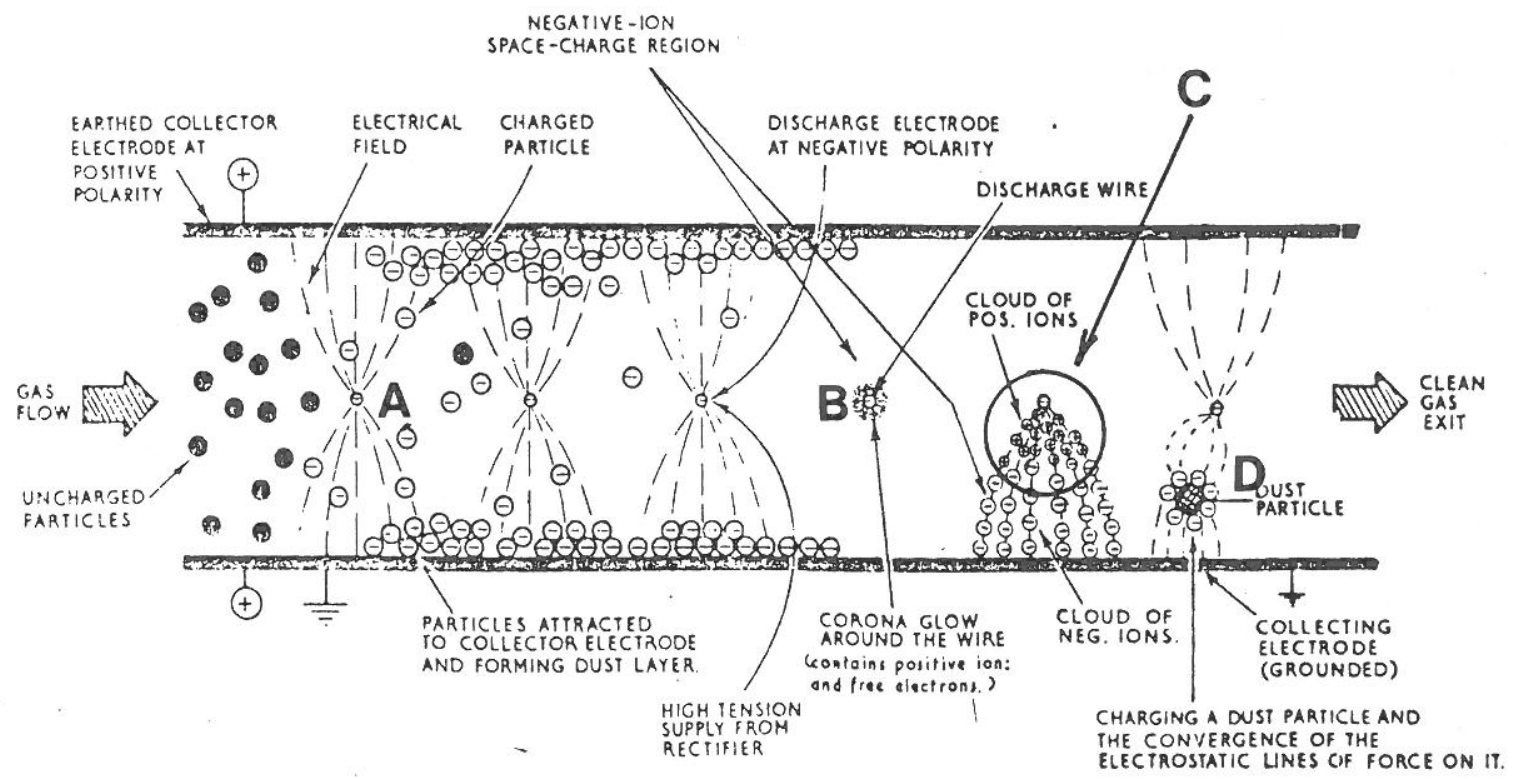

Diagram of basic principle of electrical precipitation 
A discussion of the Deutsch formulae demonstrates the critical effect of applied voltage on migration velocity and hence on efficiency. This leads to the effect of various types of energisation, such as pulsing and the effect on the electric field when dust particles are introduced. These dust particles are attracted to the collecting surfaces from where they must be removed for disposal. At this point, the mechanism of back corona formation is described together with the method of detecting it. There are a number of factors affecting collection efficiency related to the primary plant. These are, gas volume and temperature, particle resistivity, inlet loading and gas distribution. Other factors are peculiar to the precipitator, the most critical being the functioning of the control system.

The most common form of controller still in operation is the analog type, although this is being superseded by the more sophisticated digital types. The analog controller optimises voltage by seeking sparkover. It has several disadvantages, its slow response rate and inability to deal with back corona. These disabilities have been overcome with the new micro-processors which are not only much faster, but have a memory function and can be programmed to execute complicated procedures.

Since commercial controllers have varying capabilities, a number are examined in order that the student may recognise the equipment best suited to his needs.

Module 3 is entitled "Operation and Maintenace". First of all, it looks at factors related to the primary plant and how these affect the precipitator collection efficiency. It must be realised that an electrostatic precipitator will only operate as specified if all the input conditions are met. Variations in gas volume, temperature, gas distribution, inlet dust loading, all have an effect, particularly if a number of adverse conditions exist together. Gas conditioning has been effective in controlling particle resistivity in some instances and improving collection efficiency. Conditions within the precipitator itself can be diagnosed only if adequate instrumentation is installed and the operator is trained in interpreting the readings. A number of types of malfunction can be diagnosed in this way.

Regarding maintenance, this may be either in service, or while the plant is shut down. It is stated in the notes that "If the operator would pay attention to nothing else, the three main aspects contributing to effective running of the precipitator are readings, rappers and hoppers". When entering a precipitator casing for internal inspection a number of safety requirements must be complied with and the correct documentation completed. The items that should be inspected during both short period shutdown and during major overhaul are detailed. Perhaps the most important items are rapping gear, electrode alignment, dust built-up and air leaks into the casings.

When preparing the unit for service, a prescribed procedure is carried out, one important aspect being the still air energisation test of each electrical section.

Finally, in Module 4 we look at problems and troubleshooting. Again, the instrument readings are vital in this regard, giving the first indication of malfunction. Rapping faults are prevalent, chiefly in the larger units and frequently these can be detected with the unit operating. Troubleshooting by internal inspection involves an examination of the extent and nature of dust build-up, an investigation of the anti-sneakby baffles and electrode alignment.

This module is supported by a number of annexures. The first deals with gas conditioning. Gas conditioning is not a new concept, the effect of $\mathrm{SO}_{3}$ on precipitator performance being noted as early as 1912. The theory and application of conditioning agents is discussed together with guidelines on determining the correct agent to use for a particular application. The next annexure deals with the opacity meter. It describes the folded path monitor and defines the terms used, explaining the difference between opacity and optical density. When discussing the principle of measurement, guidelines are given how to choose the correct scale for a particular application. Finally, the observed opacity is at the stack outlet. Readings in the flue must, therefore, be corrected to stack opacity as seen by an observer at ground level.

Isokinetic sampling is a method of determining the actual dust burden in the emitted gas. This is an expensive procedure not normally performed by industry "in house". However, it is important to realise how tests are carried out, sampling points selected, the measurement techniques and the accuracy that can be anticipated from the results.

An aspect, usually not given adequate attention, is the legal and safety concepts. Apart from the normal safety regulations, a number of statutory acts govern safety in the work place. These provide for criminal liability in the event of death or injury resulting from contravention of any of the aspects of the legislation. A number of these provide for environmental protection, such as the Atmospheric Pollution Prevention Act and the Water Act. However, the Mines Act (at present being redrafted) and in particular the Machinery and Occupational Safety Act (MOSACT) provide for criminal liability. The function of these acts is discussed and the manner in which liability can arise. It is worthwhile to note that any person who 
fails to use safety equipment at a workplace, that was issued to him. is guilty of an offence. This applies also to a visitor who. for instance, does not wear a hard hat provided for hiın.

The question of effective earthing of an electrostatic precipitator and its components has received special mention. This aspect requires more attention than it normally receives, as very effective earthing of the precipitator and its components is essential for the efficient and safe operation of the plant. Not only does effective earthing provide a low resistance path necessary to complete the H.V. circuit, but it ensures that the voltage disturbances inside the casing, that are required to be sensed by automatic control systems, are correctly interpreted enabling the controller to function as designed. High frequency voltage peaks generated during sparking can be a danger to cabling and other electrical equipment.

The necessity for examination of all earthing connections on a regular basis is emphasised and guidelines are laid down as to the procedures and standards required to effect adequate earthing. The maximum resistance to earth, including the earthing system itself, from any point in the precipitator or its components, should not exceed two ohms.

\section{KORTKURSUS IN DIE BEDRYF EN ONDERHOUD VAN ELEKTROSTATIESE PRESIPITEERDERS AANGEBIED DEUR DIE TECHNIKON PRETORIA EN DIE WNNR IS UITERS GEWILD}

Die APCOT komitee, onder die beskerming van die WNNR, het deur middel van vraelyste die belangrikheid van opleiding in die bedryf en onderhoud van elektrostatiese presipiteerders geidentifseer. Die feit dat meer as $70 \%$ van alle gassuiwering in Suid-Afrika deur middel van elektrostatiese presipiteerders gedoen word sodat R500 miljoen die afgelope 15 jaar aan hierdie suiweringsapparaat bestee is het tot gevolg dat die persone wat hierdie toerusting bedryf, behoorlik opgelei moet wees vir hierdie doel.

APCOT en die Technikon Pretoria het na vele samesprekings besluit om 'n kortkursus oor bogenoemde onderwerp aan te bied. 'n Uiters volledige handleiding is met die hulp van Mnr Harold Egenes en Mnr Chris Albertyn van die WNNR saamgestel, wat as amptelike kursushandleiding gebruik word. Die kursus strek oor 'n tydperk van 3 dae voltydse klasbywoning by die Technikon Pretoria waartydens veral klem gelê word op die praktiese aspekte van die bedryf en onderhoud van hierdie apparaat. 'n Praktiese besoek aan die nywerheid word ook ingesluit. Aan die einde van die tydperk word 'n interne Technikon eksamen afgelê en aan alle suksesvolle kandidate word 'n Technikon sertifikaat uitgereik.
Hierdie kursus blyk uiters gewild te wees by die nywerhede wat sulke toerusting bedryf aangesien die twee kursusse wat tot op datum aangebied is vooraf volbespreek was. 76 Persone vanuit al die uithoeke van die Republiek van Suid-Afrika en selfs naburige State soos Swaziland het die twee kursusse bygewoon. Terugvoering wat vanaf persone wat alreeds die kursus bygewoon het, beklemtoon die nut en toepassingswaarde van die kortkursus. 'n Vraelys oor sakfilters wat huidiglik in sirkulasie is sal bepaal of daar 'n behoefte binne hierdie veld bestaan.

Daar word beoog om gedurende November 1989 'n herhaling van bogenoemde kursus aan te bied. Vir enige navrae in verband met hierdie kortkursus asook enige ander voorstelle oor moontlike ander kortkursusse skakel asseblief met:

Mnr J C Engelbrecht

Hoof: Departement Omgewingsgesondheid

Skool vir Gesondheidswetenskappe

Technikon Pretoria

Kerkstraat 420

PRETORIA. 0002

TEL.: $318-5282$ 